\begin{tabular}{|c|l|}
\hline Title & Adsorption of egg al bumin onto methylated yeast biomass \\
\hline Author(s) & Seki, Hideshi; Suzuki, A kira; Maruy ama, Hideo \\
\hline Citation & $\begin{array}{l}\text { Journal of Colloid and Interface Science, 270(2), 304.308 } \\
\text { https://doi.org/40.1016/.jcis.2003.09.039 }\end{array}$ \\
\hline Issue Date & 2004.02-15 \\
\hline Doc URL & http://hdl.handle.net/2115/44071 \\
\hline Type & article (author version) \\
\hline File Information & 2004a.pdf \\
\hline
\end{tabular}

Instructions for use 


\title{
Adsorption of Egg Albumin to Methylated Yeast Biomass
}

HIDESHI SEKI, AKIRA SUZUKI AND HIDEO MARUYAMA

\author{
Division of Marine Biosciences, Graduate School of Fisheries Sciences, \\ Hokkaido University, \\ Minato-cho 3-1-1 Hakodate 041-8611, Japan
}

\begin{abstract}
Abbreviated title:
EGG ALBUMIN ADSORPTION TO METHYLATED YEAST
\end{abstract}

Hideshi Seki

Division of Marine Biosciences, Graduate School of Fisheries Sciences

Hokkaido University,

Minato-cho 3-1-1 Hakodate 041-8611, Japan

E-mail: seki@elsie.fish.hokudai.ac.jp. 


\begin{abstract}
A new biosorbent, methylated yeast (MeYE), was prepared for the adsorptive separation of proteins from aqueous solutions. Yeast was methylated in a $0.1 \mathrm{M} \mathrm{HCl}$ methyl alcohol solution at room temperature. About $80 \%$ of the carboxylic groups of yeast could be methylated within 9 h. The adsorption of egg albumin to MeYE was studied to evaluate the protein adsorption ability of MeYE. At near neutral pH, egg albumin was scarcely adsorbed to unmethylated yeast and the adsorption amount of egg albumin increased with increasing the methylation degree. The adsorption amount of egg albumin to MeYE increased with increasing $\mathrm{pH}$ from 4 to 7 and steeply decreased above $\mathrm{pH}$ 7. The Langmuir isotherm was applied to determine the apparent adsorption constant and the saturated adsorption amount of egg albumin to MeYE. Both the apparent adsorption constant and the saturated adsorption amount increased with the degree of methylation. The saturated adsorption amount of egg albumin to MeYE having methylation degree 77\% was $8.41 \times 10^{-6} \mathrm{~mol} \mathrm{~g}^{-1}$ or $0.378 \mathrm{~g} \mathrm{~g}^{-1}$ at near neutral $\mathrm{pH}$.
\end{abstract}

Key Words: methylation, yeast biomass, adsorption, protein, egg albumin 


\section{INTRODUCTION}

The recovery and purification of protein products from various biological feed streams (protein bioseparation) is an important unit operation in the food, pharmaceutical and biotechnological industry. The protein bioseparation is a time and cost consuming process and it often accounts for a significant percentage of the total processing cost. Thus, many protein bioseparation techniques such as precipitation, centrifugation, filtration, chromatography, and adsorption have been investigated to develop efficient and cost-effective technologies. The concentrations of target proteins in biological feed streams are generally very low and they need to be separated from a large number of impurities. Therefore, high-productivity (low-resolution) techniques are used first for the overall concentration of the feed stream. This is followed by highresolution techniques for further purification of the target protein.

Adsorption is an effective and convenient technique in the primary bioseparation step since this technique can treat large liquid streams. Thus the studies on the protein adsorption onto various surfaces in aqueous systems has been studied over the past few decades by many researchers (1-5). Recently, Peet et al. (4) have proposed a new technology, centrifugal adsorption technology (CAT), for efficient adsorption from large liquid streams by using adsorbent particles in the micrometer range. CAT seems particularly suited for 
the recovery of macromolecules at low concentrations, because the small particle dimensions lead to fast mass transfer rates.

On the other hand, the use of microorganisms for the adsorptive separation of heavy metals from aqueous environment (biosorption) has attracted much attention in recent years. Many types of microorganisms have been investigated for use in this application (6-15). Microorganisms would be suited for the use in CAT, because they have a size in the micrometer range. However, the use of microorganisms for the adsorptive separation of proteins from aqueous solutions has been scarcely investigated.

In this study, a common and inexpensive microorganism, yeast, was applied to the adsorptive separation of egg albumin from aqueous solution. Most microorganisms have a negative surface charge at near neutral $\mathrm{pH}(16$, 17). Egg albumin, used as a model adsorbate in this study, has its isoelectric point at about $\mathrm{pH} 4.5$ and it also has a negative charge above $\mathrm{pH} 4.5$. Therefore, it is expected that egg albumin can hardly adsorb to yeast surface at near neutral $\mathrm{pH}$.

Fraenkel-Conrat and Olcott (18) reported that the carboxylic groups of proteins were readily methylated at room temperature in methyl alcohol containing small amounts of mineral acid $\left(0.02\right.$ to $\left.0.1 \mathrm{~mol} \mathrm{dm}^{-3}\right)$. The acidcatalyzed reaction of proteins with methanol was a specific one involving only 
the carboxylic groups; amino, phenolic, thiol, and indole groups and peptide and amide bonds were unaffected. The main negatively charged group on the surface of microorganisms is carboxylic group $(11,14,17)$. Therefore, it is expected that the highly methylated yeast surface become to have a positive charge at near neutral $\mathrm{pH}$ and it can act as an adsorbent for negatively charged egg albumin.

In the present study, we prepared methylated yeast (MeYE) having a methylation degree of $23,54,68$, and $77 \%$ according to the method reported by Fraenkel-Conrat and Olcott (18). To confirm the effect of methylation on the adsorption behavior of egg albumin to MeYE, adsorption experiments were performed at the $\mathrm{pH}$ range from $\mathrm{pH} 4$ to $\mathrm{pH} 8$. Then we applied the Langmuir adsorption isotherm to the experimental data. Based on the Langmuir parameters, the effect of methylation on the adsorption ability of MeYE for egg albumin will be discussed. 


\section{MATERIALS}

\section{Chemicals}

Albumin (from egg), methyl alcohol, sodium chloride, sodium hydroxide, and hydrochloric acid were purchased from Kanto Chemical Co. Inc. (Japan). Albumin was of practical-grade quality and other chemicals were of reagentgrade quality. They were used with no further purification. Distilled water, boiled for 15 min and cooled under a nitrogen atmosphere, was used in all experiments.

\section{Methylated Yeast}

Yeast (dried) of practical-grade was purchased from Wako Pure Chemical Industries (Japan) and it was washed in the following manner. A $100 \mathrm{~g}$ of yeast was suspended in a $1 \mathrm{dm}^{3}$ of $0.01 \mathrm{M} \mathrm{NaOH}$ solution and mechanically stirred for $2 \mathrm{~h}$. The yeast was separated in a centrifuge at 3,300 rpm for $30 \mathrm{~min}$ and washed repeatedly with distilled water. Then it was suspended in a $1 \mathrm{dm}^{3}$ of methyl alcohol and stirred at room temperature. After $24 \mathrm{~h}$ of stirring, yeast was separated in a centrifuge at 3,300 rpm for $30 \mathrm{~min}$, and it was freeze-dried and ground to a fine powder. The ground yeast was sieved through a 120-mesh $(0.125 \mathrm{~mm})$ sieve and the undersize fraction was used. Hereafter, the yeast will 
be abbreviated as YE.

Methylated yeast was prepared according to the method reported by Fraenkel-Conrat and Olcott (18). A $10 \mathrm{~g}$ of YE was dispersed in a $1 \mathrm{dm}^{3}$ of methyl alcohol containing $\mathrm{HCl}\left(0.1 \mathrm{~mol} \mathrm{dm}^{-3}\right)$ as a catalyst and mechanically stirred at room temperature. The methylated yeast was collected in a centrifuge at 3,300 rpm for 20 min and washed repeatedly with distilled water. Then it was freeze-dried and stored in a desiccator. Hereafter, the methylated yeast will be abbreviated as MeYE. In this study, we used four types of MeYE that have a methylation degree of $23,54,68$, and $77 \%$. They were prepared by changing the methylation time $1.5,3,6$, and $9 \mathrm{~h}$, respectively. 


\section{EXPERIMENTAL METHODS}

\section{Potentiometric Titration of MeYE and YE}

The degree of methylation was determined from the change in the number of carboxylic groups before and after methylation. The number of carboxylic groups was determined by a potentiometric titration. A solution $\left(0.3 \mathrm{dm}^{3}\right)$ containing $1.0 \mathrm{~g} \mathrm{dm}^{-3}$ of $\mathrm{MeYE} / \mathrm{YE}$ was mechanically stirred at $30^{\circ} \mathrm{C}$. The ionic strength of the solution was adjusted to $0.1 \mathrm{~mol} \mathrm{dm}^{-3}$ by the addition of $\mathrm{NaCl}$. To eliminate $\mathrm{CO}_{2}$, the titration was performed under nitrogen atmosphere. After reaching thermal equilibrium, the solution was titrated with a volumetric standard solution of $\mathrm{HCl}$ or $\mathrm{NaOH}\left(0.1 \mathrm{~mol} \mathrm{dm}^{-3}\right)$. The $\mathrm{pH}$ of the solution was measured by using a pH meter (Orion Research 520-A). The number of protonated acidic groups was determined from the difference between the bulk proton concentrations in the presence of MeYE/YE and those in the absence of MeYE/YE.

\section{Adsorption of Egg Albumin}

A solution $\left(90 \mathrm{~cm}^{3}\right)$ of $\mathrm{NaCl}\left(0.1 \mathrm{~mol} \mathrm{dm}^{-3}\right)$ containing MeYE/YE (1.0 g $\mathrm{dm}^{-3}$ ) was prepared. The $\mathrm{pH}$ of the solution was adjusted to the desired value with $\mathrm{HCl}$ or $\mathrm{NaOH}$. After the thermal equilibrium was reached at $30 \square, 10 \mathrm{~cm}^{3}$ 
of a solution $\left(10 \mathrm{~g} \mathrm{dm}^{-3}\right)$ containing a certain amount of egg albumin was added to the suspension. The suspension was stirred for the time necessary to attain the adsorption equilibrium, and then MeYE/YE was separated from the liquid phase in a centrifuge (Kokusan $\mathrm{H}-1500 \mathrm{~F}$ ) at 3,300 rpm for $20 \mathrm{~min}$. The $\mathrm{pH}$ and egg albumin concentration of the supernatant were measured. The concentration of egg albumin was determined with a spectrophotometer (Hitachi U-1500) at $280 \mathrm{~nm}$. The amount of egg albumin adsorbed to MeYE/YE was determined from the difference between the egg albumin concentrations in the initial and the equilibrium states. The molar concentration of egg albumin was calculated assuming the molecular weight as $45,000$. 


\section{RESULTS AND DISCUSSION}

\section{Determination of Methylation Degree}

Figure 1 shows a typical example of the proton adsorption isotherm of MeYE (methylated for 9h) obtained from potentiometric titration (open circles). As for the comparison, the result of YE is also presented in Fig. 1 (solid circles). The ordinate of the figure, $X_{H}$, represents the equilibrium number of protons bound to 1 dry-g of MeYE/YE. The $X_{H}$ values of MeYE and YE are almost the same at above $\mathrm{pH}$ 5, while the $X_{H}$ values of MeYE is considerably lower than that of YE at below pH 5.

The proton adsorption isotherm of microorganisms are usually broad and ill defined, thus reflecting the diversity in the proton binding sites. The proton binding sites of microorganisms can be divided into three main types $(9,11$, 14, 17). The total adsorption amount of proton to 1-dry g of microorganism, $X_{H}$, can be expressed by the following equation $(11,14)$.

$$
X_{H}=N_{H 1}\left[\mathrm{H}^{+}\right] /\left(K_{H 1}+\left[\mathrm{H}^{+}\right]\right)+N_{H 2}\left[\mathrm{H}^{+}\right] /\left(K_{H 2}+\left[\mathrm{H}^{+}\right]\right)+N_{H 3}\left[\mathrm{H}^{+}\right] /\left(K_{H 3}+\left[\mathrm{H}^{+}\right]\right)
$$

where $K_{H}$ and $N_{H}$ represent the dissociation constants of proton binding sites and the number of binding sites on 1-dry g of microorganism, respectively. A 
nonlinear least-squares method was applied to find the constants, $K_{H}$ and $N_{H}$, of three type sites. The constants for YE which gave the best fit with the experimental data are listed in Table 1 . Type 1 site, which has the aciddissociation constant of $p K_{H 1}=3.73$, can be considered as the carboxylic groups. As mentioned above, the acid-catalyzed reaction of proteins with methanol was a specific one involving only the carboxylic groups. Therefore, the number of carboxylic groups of MeYE was determined using the same constants as YE except $N_{H 1}$. The number of carboxylic groups of MeYE methylated for $9 \mathrm{~h}$ decreased to $0.077 \mathrm{mmol} \mathrm{g}^{-1}$ and the methylation degree of the present MeYE was obtained to be 77 \%. The solid lines in Fig. 1 represent the theoretical curve calculated from Eq. [1]. The experimental results agreed well with the theoretical values calculated using Eq. [1] and at pH above 5 the $X_{H}$ values of MeYE coincided well with that of YE. The result suggests that the present methylation reaction did not affect any functional group other than the carboxylic groups.

pH Dependence of Egg Albumin Adsorption to MeYE

The $\mathrm{pH}$ dependence of egg albumin adsorption to MeYE is shown in Fig. 2. Preliminary kinetic experiments for the egg albumin-MeYE system were conducted. Since MeYE does not have porous structure, the adsorption 
proceeded rapidly and 30 min or so was enough to attain the equilibrium. From the results, we determined the contact time for the equilibrium experiments as 2 h. The ordinate, $X\left(\mathrm{~mol} \mathrm{~g}^{-1}\right)$, of Fig. 2 represents the adsorption amount of egg albumin to 1 dry-g of MeYE/YE at equilibrium. MeYE methylation degree of $23,54,68$, and $77 \%$ were used in the experiment. As for the comparison, the result of YE was also presented. The initial concentration of egg albumin was $1.0 \times 10^{-5} \mathrm{~mol} \mathrm{dm}^{-3}$. In the case of YE, only a small amount of egg albumin was adsorbed at about $\mathrm{pH} 4.5$ (which is the iso-electric point of egg albumin). The adsorption amount of egg albumin at near neutral $\mathrm{pH}$ increased significantly with increasing the methylation degree. The result suggests that the yeast surface has been modified to have a positive charge by the methylation and thus the adsorption amount of negatively charged egg albumin has increased with increasing the methylation degree.

The adsorption amount of egg albumin to MeYE increased with increasing $\mathrm{pH}$ from 4 to 6 and steeply decreased above $\mathrm{pH}$ 7. The number of positively charged amino groups on MeYE is constant in the $\mathrm{pH}$ range, while the net negative charge density of egg albumin steeply increases above $\mathrm{pH}$ 4.5. The attractive force between the positively charged MeYE surface and the negatively charged egg albumin may become stronger with increasing the net negative charge density of egg albumin, and thus the adsorption amount 
increase with increasing $\mathrm{pH}$ from 4 to 6 . On the other hand, the number of negatively charged phosphatic groups on MeYE steeply increases above pH 6 . Although the number of positively charged amino groups on MeYE is constant below $\mathrm{pH}$ 8, the net positive charge density of MeYE should decrease with increasing the number of negatively charged phosphatic groups. Thus, the adsorption amount of egg albumin steeply decreased above pH 7.

Adsorption Isotherm of Egg Albumin to MeYE

Figure 3 shows the adsorption isotherm of egg albumin to MeYE at $\mathrm{pH}$ 6.5 \pm 0.2 . The abscissa, $C\left(\mathrm{~mol} \mathrm{dm}^{-3}\right)$, of Fig. 3 represents the equilibrium concentration of egg albumin. According to the literature (19-21), adsorption of egg albumin to MeYE/YE has been described by the Langmuir isotherm:

$$
K=X /(N-X) C
$$

or

$$
C=N C / X-1 / K
$$

where $K\left(\mathrm{dm}^{3} \mathrm{~mol}^{-1}\right)$ and $N\left(\mathrm{~mol} \mathrm{~g}^{-1}\right)$ are the apparent adsorption constant and 
the saturated adsorption amount of egg albumin, respectively. Figure 4 shows the Langmuir plot of the experimental data in Fig. 3. The adsorption of egg albumin to MeYE and YE agreed well with the Langmuir isotherm and the apparent adsorption constants and the saturated adsorption amounts were determined from the slopes and intercepts of the lines in Fig. 4. The constants, $K$ and $N$, and the correlation coefficients between the experimental and the predicted values, $R^{2}$, were listed in Table 2. Both the apparent adsorption constant and the saturated adsorption amount increased markedly with increasing the methylation degree. As mentioned above, the methylation reaction has no effect on any functional groups other than the carboxylic groups and the number of positively charged amino groups on the yeast surface is constant below pH8. Thus, it is obvious that the negatively charged carboxylic groups on the yeast surface inhibit the adsorption of egg albumin.

The saturated adsorption amount of MeYE methylation degree of $77 \%$ was $8.41 \times 10^{-6} \mathrm{~mol} \mathrm{~g}^{-1}$ or $0.378 \mathrm{~g} \mathrm{~g}^{-1}$. Gun'ko et al. (1) studied the adsorption of bull serum albumin to fumed silica (Aerosil A-300, diameter ca. $2 \mu \mathrm{m}$, specific surface area ca. $300 \mathrm{~m}^{2} \mathrm{~g}^{-1}$ ) at about $\mathrm{pH}$ 6. The saturated adsorption amount of bull serum albumin to fumed silica was about $0.5 \mathrm{~g} \mathrm{~g}^{-1}$ and it was slightly larger than that of egg albumin to MeYE. However, the saturated adsorption amount of egg albumin to MeYE was much larger than those of catalase to a 
hydroxyl apatite (specific surface area $80 \mathrm{~m}^{2} \mathrm{~g}^{-1}$ ) at pH6.8, $0.08 \mathrm{~g} \mathrm{~g}^{-1}$ (2), bovine serum albumin and lysozyme to hydrophobic calcium hydroxyapatites (specific surface area $90 \mathrm{~m}^{2} \mathrm{~g}^{-1}$ ) at $\mathrm{pH} 6,0.135 \mathrm{~g} \mathrm{~g}^{-1}$ (3), bovine serum albumin to a strong anion-exchange resin (Macroprep High Q, diameter $50 \mu \mathrm{m}$ ) at $\mathrm{pH}$, $0.037 \mathrm{~g} \mathrm{~cm}^{-3}$ (4), and human serum albumin to a colloidal $\mathrm{TiO}_{2}$ (primary particle size 30nm) at $\mathrm{pH} 6,0.125 \mathrm{~g} \mathrm{~g}^{-1}(5)$. 


\section{CONCLUSION}

A common and inexpensive biomass, yeast was applied to the adsorptive separation of proteins from aqueous solutions. Yeast was methylated according to the method reported by Fraenkel-Conrat and Olcott. The adsorption behavior of egg albumin to methylated yeast having a methylation degree of $23,54,68$, and $77 \%$ was investigated at $\mathrm{pH}$ from 4 to 8 . Egg albumin was scarcely adsorbed to unmethylated yeast at near neutral $\mathrm{pH}$ and only a small amount of egg albumin was adsorbed to unmethylated yeast at an isoelectric point of egg albumin ( $\mathrm{pH}$ 4.5). The adsorption amount of egg albumin to methylated yeast increased with increasing the methylation degree. The adsorption amount of egg albumin increased with increasing $\mathrm{pH}$ from 4 to 7 and steeply decreased above $\mathrm{pH}$ 7. The adsopriton of egg albumin was well described by the Langmuir isotherm. Both the apparent adsorption constant and the saturated adsorption amount increased with the degree of methylation. Methylated yeast having a methylation digree of $77 \%$ had a rather large adsorption capacity of $8.41 \times 10^{-6} \mathrm{~mol} \mathrm{~g}^{-1}$ or $0.378 \mathrm{~g} \mathrm{~g}^{-1}$ for egg albumin at $\mathrm{pH}$ 6.5 . 


\section{NOMENCLATURE}

$$
\begin{array}{lll}
C & =\text { Equilibrium concentration of egg albumin } & {\left[\mathrm{mol} \mathrm{dm}^{-3}\right]} \\
K & =\text { Adsorption constant of egg albumin } & {\left[\mathrm{dm}^{3} \mathrm{~mol}^{-1}\right]} \\
K_{H} & =\text { Dissociation constant of acidic/basic groups on MeYE/YE }\left[\mathrm{dm}^{3} \mathrm{~mol}^{-1}\right] \\
N & =\text { Saturated adsorption amount of egg albumin } & {\left[\mathrm{mol} \mathrm{g}^{-1}\right]} \\
N_{H} & =\text { Number of acidic/basic groups on MeYE/YE } & {\left[\mathrm{mol} \mathrm{g}^{-1}\right]} \\
X & =\text { Equilibrium adsorption amount of egg albumin } & {\left[\mathrm{mol} \mathrm{g}^{-1}\right]} \\
X_{H} & =\text { Equilibrium adsorption amount of proton } & {\left[\mathrm{mol} \mathrm{g}^{-1}\right]}
\end{array}
$$




\section{REFERENCES}

1. V. M. Gun'ko, V. V. Turov, V. I. Zarko, V. V. Dudnik, V. A. Tischenko,

O. A. Kazakova, E. F. Voronin, S. S. Siltchenko, V. N. Barvinchenko, A.

A. Chuiko, J. Colloid Interface Sci. 192 (1997) 166.

2. A. Barroug, E. Lernoux, J. Lemaitre, P. G. Rouxhet, J. Colloid Interface Sci. 208 (1998) 147.

3. K. Kandori, M. Mukai, A. Fujiwara, A. Yasukawa, T. Ishikawa, J. Colloid Interface Sci. 212 (1999) 600.

4. D. J. Peet, M. A. T. Bisschops, S. H. van Hateren, L. A. M. van der Wielen, Biotechnol. Bioeng. 78 (2002) 237.

5. F. Y. Oliva, L. B. Avalle, O. R. Camara, C. P. De Pauli, J. Colloid Interface Sci. 261 (2003) 299.

6. H. Niu, X. S. Xu, J. H. Wang, B. Volesky, Biotechnol. Bioeng. 42 (1993) 785.

7. B. Volesky, H. May, Z. R. Holan, Biotechnol. Bioeng. 41 (1993) 826.

8. J. Chang, J. Hong, Biotechnol. Bioeng. 44 (1994) 999.

9. A. C. C. Plette, M. F. Benedetti, W. H. van Riemsdijk, Environ. Sci. Technol. 30 (1996) 1902.

10. L. E. Macaskie, P. Yong, T. C. Doyle, M. G. Roig, M. Diaz, T. Mnzano, 
Biotechnol. Bioeng. 53 (1997) 100.

11. H. Seki, A. Suzuki, S. Mitsueda, J. Colloid Interface Sci. 197 (1998) 185.

12. M. I. Kefala, A. I. Zouboulis, K. A. Matis, Environ. Pol. 104 (1999) 283.

13. B. Chen, V. P. Utgikar, S. M. Harmon, H. H. Tabak, D. F. Bishop, R. Govind, Int. Biodet. Biodeg. 46 (2000) 11.

14. H. Seki, A. Suzuki, Y. Iburi, J. Colloid Interface Sci. 229 (2000) 196, jcis.2000.6998.

15. H. Seki, A. Suzuki, J. Colloid Interface Sci. 249 (2002) 295, jcis.2002.8297.

16. K. C. Marshall, Aust. J. Biol. Sci. 20 (1967) 429.

17. A. C. C. Plette, W. H. van Riemsdijk, M. F. Benedetti, A. van der Wal, J. Colloid Interface Sci. 173 (1995) 354.

18. H. Fraenkel-Conrat, H. S. Olcott, J. Biol. Chem. 161 (1945) 259.

19. R. K. R. Phillips, S. Omanovic, S. G. Roscoe, Langmuir 17 (2001) 2471.

20. G. Bayramoğlu, M. Y. Arica, Colloids Surf. A 202 (2002) 41.

21. G. M. S. Finette, Q. Mao, T. W. Hearn, J. Chromato. A 763 (1997) 71. 


\section{TABLE 1}

Equilibrium Parameters for the Acid Dissociation of Yeast

\begin{tabular}{lccc}
\hline & Type 1 & Type 2 & Type 3 \\
$p K_{H}$ & 3.73 & 6.24 & 9.64 \\
$N_{H}\left(\mathrm{mmol} \mathrm{g}^{-1}\right)$ & 0.336 & 0.199 & 0.244 \\
\hline
\end{tabular}




\section{TABLE 2}

Equilibrium Parameters for the Egg Albumin Adsorption to Methylated Yeast at pH 6.5

\begin{tabular}{cccc} 
Metylation degree & $K\left(\mathrm{dm}^{3} \mathrm{~mol}^{-1}\right)$ & $N\left(\mathrm{~mol} \mathrm{~g}^{-1}\right)$ & $R^{2}$ \\
$0 \%$ & $2.29 \times 10^{5}$ & $0.74 \times 10^{-6}$ & 0.995 \\
$23 \%$ & $3.01 \times 10^{5}$ & $2.54 \times 10^{-6}$ & 0.976 \\
$54 \%$ & $3.76 \times 10^{5}$ & $3.98 \times 10^{-6}$ & 0.985 \\
$68 \%$ & $4.46 \times 10^{5}$ & $6.43 \times 10^{-6}$ & 0.969 \\
$77 \%$ & $6.23 \times 10^{5}$ & $8.41 \times 10^{-6}$ & 0.986 \\
\hline
\end{tabular}




\section{Figure Captions}

FIG. 1. Number of protonated sites of the yeast (solid circles) and the yeast methylated for 9h (open circles). The number of protonated sites was determined by potentiometric titrations for $0.3 \mathrm{dm}^{3}$ of a suspension containing $1.0 \mathrm{~g} \mathrm{dm}^{-3}$ of yeast or methylated yeast. Ionic strength was adjusted to $0.1 \mathrm{~mol}$ $\mathrm{dm}^{-3}$ by $\mathrm{NaCl}$. The solid lines represent the theoretical curve calculated from Eq. [1].

FIG. 2. pH dependence of egg albumin adsorption to methylated yeast at $30^{\circ} \mathrm{C}$. The concentration of methylated yeast and the initial concentration of egg albumin were $1.0 \mathrm{~g} \mathrm{dm}^{-3}$ and $1.0 \times 10^{-5} \mathrm{~mol} \mathrm{dm}^{-3}$, respectively. Ionic strength was adjusted to $0.1 \mathrm{~mol} \mathrm{dm}^{-3}$ by $\mathrm{NaCl}$.

FIG. 3. Adsorption isotherm of egg albumin to methylated yeast at $30^{\circ} \mathrm{C}$ and at $\mathrm{pH} 6.5 \pm 0.2$. Ionic strength was adjusted to $0.1 \mathrm{~mol} \mathrm{dm}^{-3}$ by $\mathrm{NaCl}$. The concentration of methylated yeast was $1.0 \mathrm{~g} \mathrm{dm}^{-3}$. The solid lines represent the theoretical curves calculated using the parameters shown in Table 2.

FIG. 4. Langmuir plots of the data in Fig. 3. 


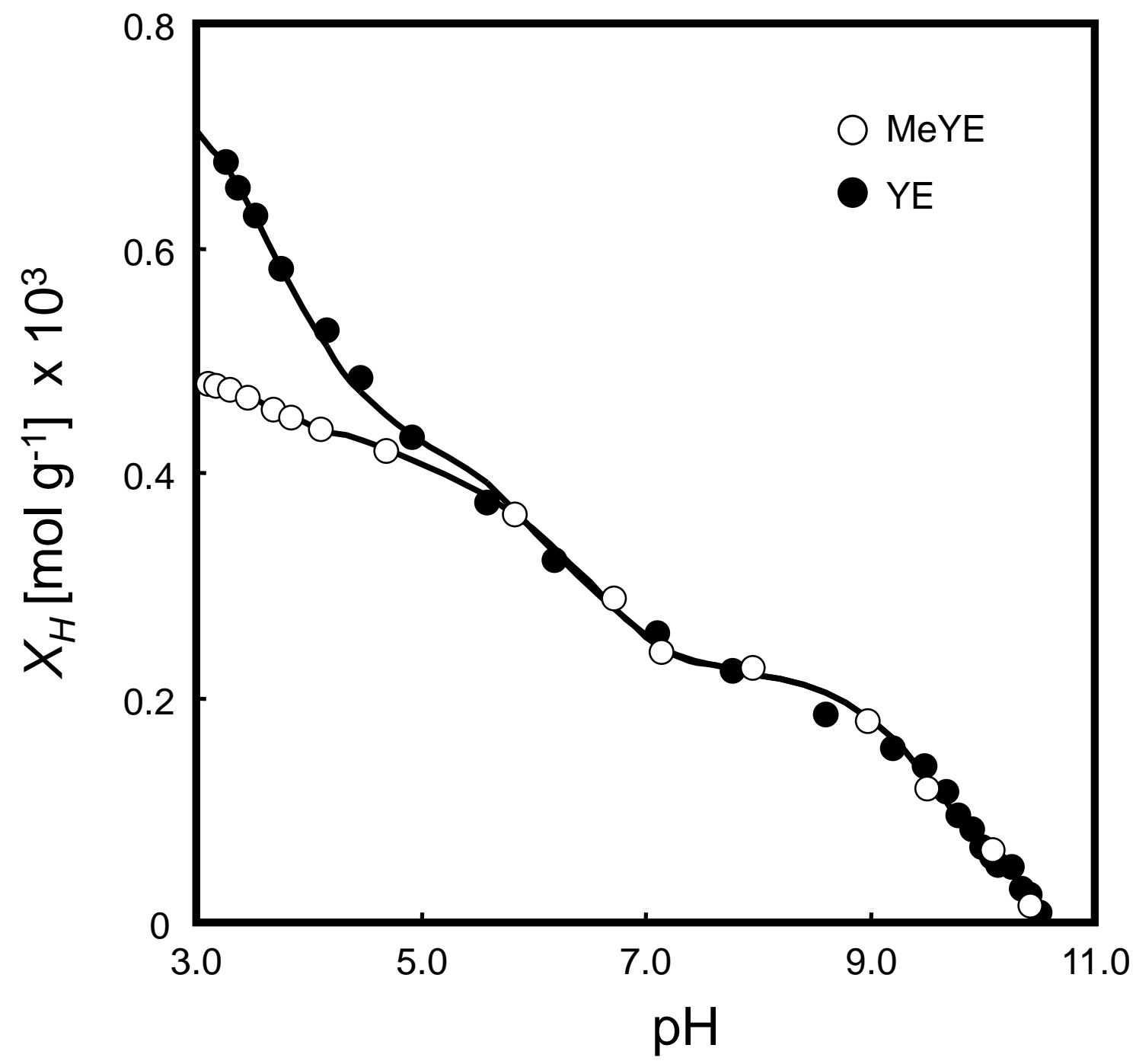

Seki et al. Fig.1 


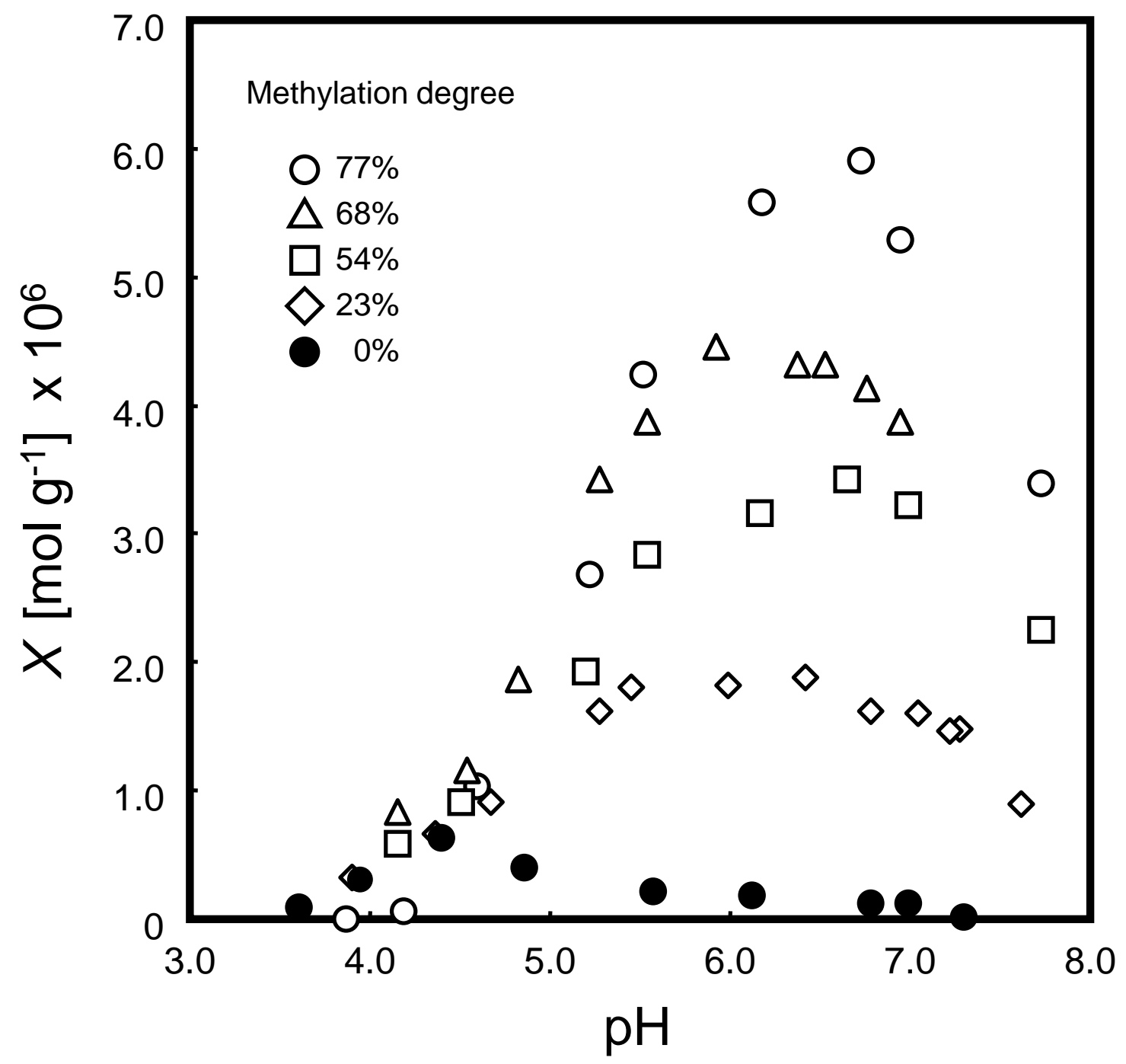




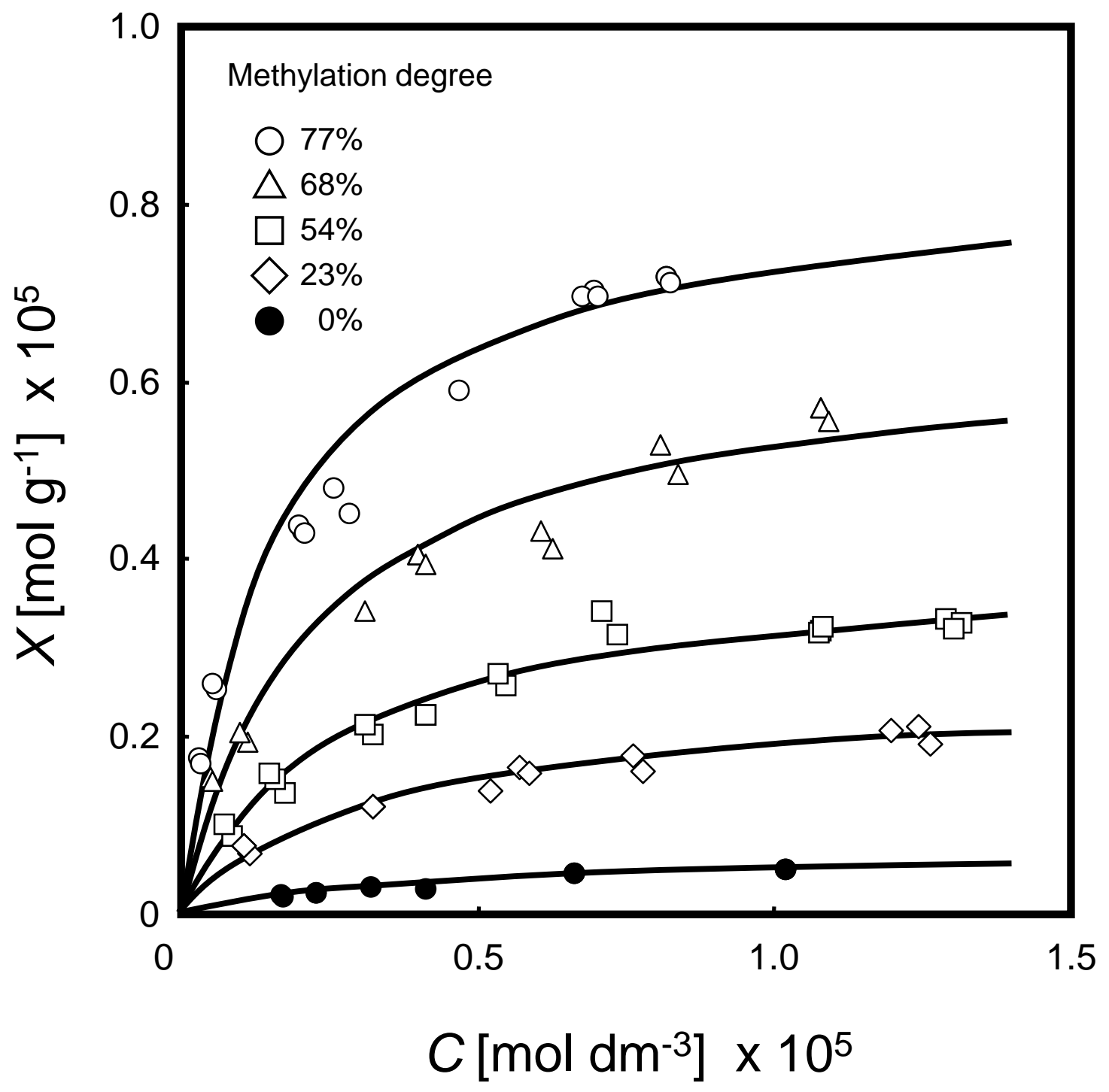

Seki et al. Fig.3 


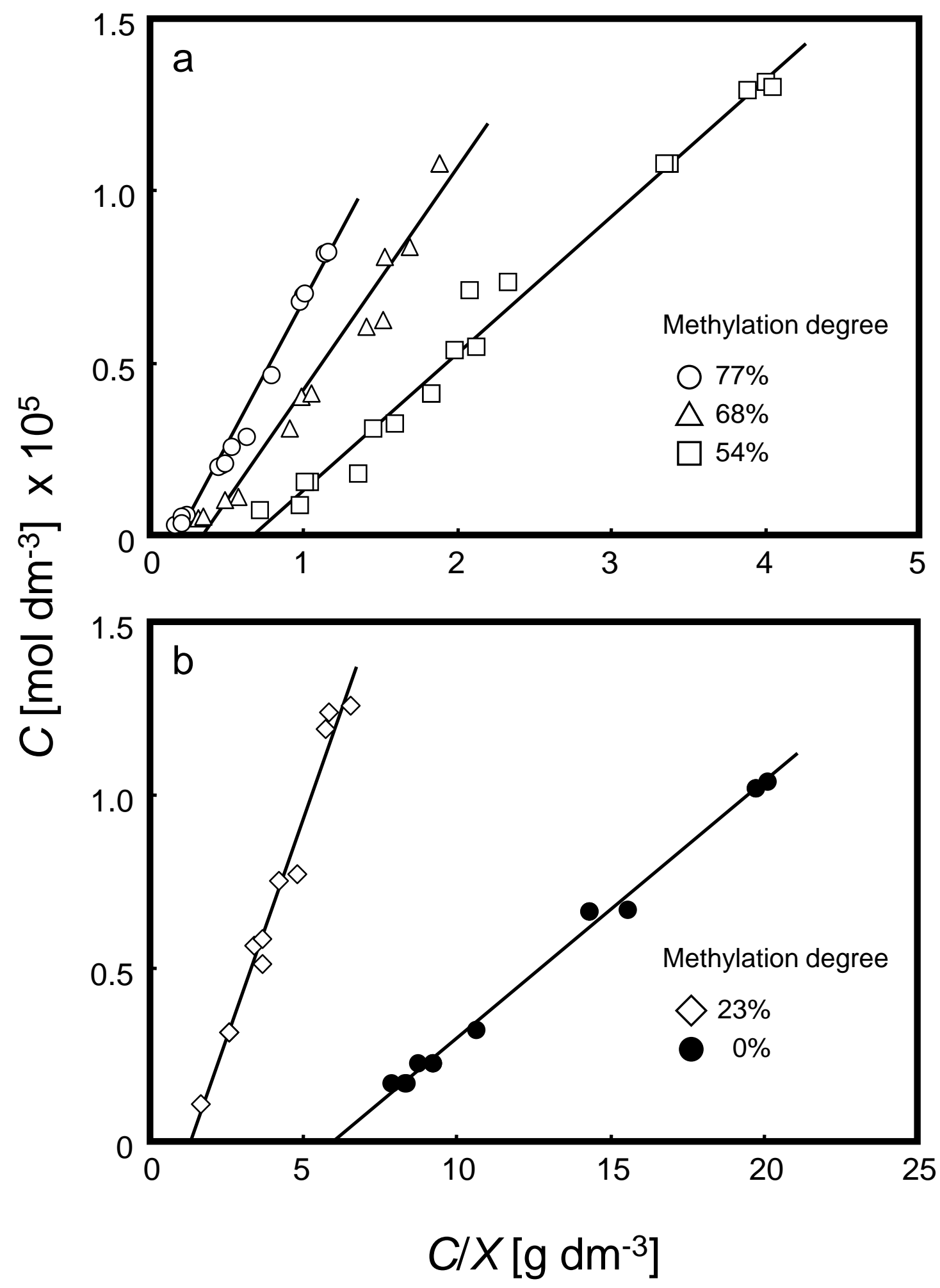

